\title{
Cosmopolitan Soirées in Eighteenth-Century North India: Reception of early Urdu poetry in Kishangarh
}

Heidi Pauwels

\section{CpenEdition}

\section{Journals}

\section{Electronic version}

URL: http://journals.openedition.org/samaj/3773

DOI: 10.4000/samaj.3773

ISSN: $1960-6060$

\section{Publisher}

Association pour la recherche sur l'Asie du Sud (ARAS)

\section{Electronic reference}

Heidi Pauwels, « Cosmopolitan Soirées in Eighteenth-Century North India: Reception of early Urdu poetry in Kishangarh », South Asia Multidisciplinary Academic Journal [Online], Free-Standing Articles, Online since 08 October 2014, connection on 19 April 2019. URL : http://journals.openedition.org/ samaj/3773 ; DOI : 10.4000/samaj.3773

This text was automatically generated on 19 April 2019

\section{(i) (9)}

This work is licensed under a Creative Commons Attribution-NonCommercial-NoDerivatives 4.0 International License. 


\title{
Cosmopolitan Soirées in Eighteenth- Century North India: Reception of early Urdu poetry in Kishangarh
}

\author{
Heidi Pauwels
}

1 The eighteenth century was a period of great cultural ferment in North India. ${ }^{1}$ It was also the period of the emergence of a new medium for poetic expression in cosmopolitan Delhi, now called Urdu, but at the time referred to as Rekhtā. ${ }^{2}$ Histories of Urdu mark as its most significant moment the arrival from the Deccan in Delhi of the poetry collection of Valī Dakanī in the year 1720/21. This import from the south caught on and became a rage, not just in the capital but in all major centers of Indo-Muslim culture (Alam 1998; Faruqi 2001, 2003). So far, no one has examined how this was perceived outside such centers, in non-Persianized milieus.

2 This article focuses on a case study of the reception of Rekhtā in the small Rajasthani principality of Kishangarh. At first sight that may seem an insignificant provincial center, but at the time it was very cosmopolitan and closely associated with the Mughal empire during the rule of Muhammad Shāh 'Rangiilā' (r. 1719-1748). The contemporary king of Kishangarh, Rāj Singh Bahādur Rāțhor (r. 1706-1748), finds little mention in the history books. Yet, his presence at the imperial court is confirmed by a wonderfully detailed source about festivals and court life during Muhammad Shāh's rule of the 1720s: Shivdās Lakhnavī's Persian Shāhnāma Munavvar Kalām (edited by Askari, see Lakhnawi 1980). This work registers gifts presented at festive occasions by and to the emperor, and there are several entries in which Rāj Singh is mentioned from the beginning of the year A.H. 1133 in the third regnal year (Lakhnawi 1980: 119-20, 123, 194 n.188). This rather unknown king turns out to have been a welcome presence at the imperial court in Delhi.

The departure point to study Kishangarh's cosmopolitanism will be two paintings of the period: one depicts a political gathering, the second a poetic one. The first portrays_Rāj Singh and the second his son Sāvant Singh (1699-1764). Sāvant Singh was the crown prince designate during Rāj Singh's rule, but he never became king because after his father's death, his younger brother usurped the throne. Sāvant Singh is best known for 
sponsoring the delicate Rādhā-Krishna paintings that made the Kishangarhi school famous, but he was also a Braj Bhāṣā poet who wrote under the pen name of Nāgrīdās. Lesser known is that he also experimented with the then-new style, later called Urdu poetry, and included Urdu poets in the anthologies he collected. Using the pictures as point of departure, the paper will present evidence of such poetic dialogues between what is now regarded as separate poetic traditions, Urdu and Braj/Hindi. The paper is based on recent manuscript research in India of Sāvant Singh's poems and collections.

Emperor Muḥammad Shāh with Courtiers and Rāj Singh of Kishangarh (attr. Dalcand)

INDIA, RAJASTHAN, KISHANgARH, CIRCA 1724. OPAQUE WATERCOLOR ON PAPER. 31.8 X 24 CM.

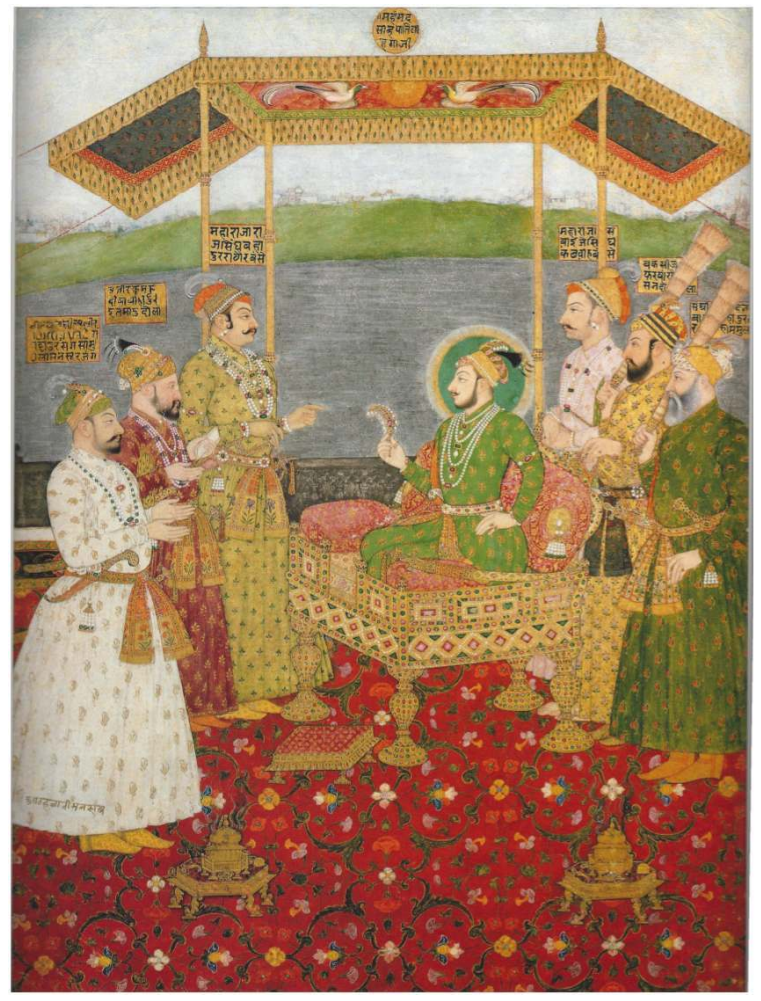

PRIVATE COLLECTION, LONDON. REPRODUCED WITH KIND PERMISSION OF THE OWNER. PHOTO COURTESY THE OWNER.

\section{A Formal Courtly Gathering in Delhi}

4 The first miniature has been attributed to the painter Dalcand (Plate 1; from a private collection in the U.K.). ${ }^{3}$ It depicts the bearded emperor Muhammad Shāh, facing Rāj Singh and two courtiers, with at his other side the Kacchvāhā ruler Savāī Jai Singh II (1688-1743) and two other courtiers. All personages portrayed are identified with Devanāgarī inscriptions. ${ }^{4}$ The two Rajputs are portrayed most prominently, and they are each accompanied by the highest Mughal office bearers: Rāj Singh is next to the top officer of the empire, the vazir, Qamr ud-Dīn Ķhān A'tmād ud-Daulah, who was a Turani, whereas Jai Singh's party includes the superintendent of the khawās, Sa'adat Ḳhān Burhān ul-Mulk, also a Mughal (see Malik 2006: 77). There are also two Indian Muslim top officials accompanying the Rajputs and their 'Mughals': the Mīr Bakhshī, Ḳhwājà 'Asīm Samsam ud-Daulah Ḳhān-e Daurān (d. 1739 at Karnal; Malik 2006: 92) with Rāj Singh, and the third 
Bakhshī, Zafar Ḳhān Roshan ud-Daulah with Jai Singh (he was appointed third Bakhshī in 1720, see Malik 2006: 76; d. 1746, ib. 274). ${ }^{5}$ These same four top Mughal administrators are also portrayed, with the, here beardless, emperor in a slightly later miniature attributable to Citarman from ca. 1730 (McInerney 2002: 24, plate 9). The portraits are identifiably the same, but Burhān ul-Mulk (here in top left position, but also behind the emperor, who faces the other way in the miniature) has a fully grey beard, whereas it is still mixed with black on the Kishangarh portrait.

5 The Kishangarh portrait plausibly represents an actual occasion at Muhammad Shāh's court. Shivdās mentions four of the same men (neither the vazir nor the superintendent of the khawass) as present at court, on the occasion of the durbar on the $1^{\text {st }}$ of the month of Ramazān AH 1133, i.e. 1721 in the third regnal year (Lakhnawi 1980: 118-9; 190 n.175), and the $9^{\text {th }}$ of Shavvāl in the same year, when the emperor is described as seated in the Diwān-e 'ām on the peacock throne, which is also depicted in the miniature. The miniature here in all likelihood depicts a similar, though slightly later, occasion. Since Qamr ud-Din obtained the vazirat in 1724 (see Malik 2006: 86), his identification with that title provides a terminus ad quem of the miniature as intended to portray a scene of 1724 or later. This may be why we don't find an exact reference in Shivdās' work, which records only events till $1724 .^{6}$ The occasion is identifiably one of gift-giving, as the emperor is holding a bejeweled object, possibly a turban ornament (sarpech), that he received from (or is about to bestow onto) Rāj Singh. The latter is pointing to the object. We have a record of Rāj Singh giving a dagger with jeweled handles on the occasion of the Naurūz celebrations on the $9^{\text {th }}$ of Shavvāl in the third regnal year (Lakhnawi 1980: 120) and receiving on the $13^{\text {th }}$ a robe of honor and embroidered headdress (together with several other recipients; 123 ). Possibly the painting was meant to commemorate similar Naurūz exchanges of a later regnal year.

6 Still, the painting was not done by the Mughal court, but one suspects it was a propaganda piece, sponsored by Rāj Singh to boast of his coziness with the new court of Muhammad Shāh. For one, the inscriptions are in Devanāgarī rather than in Nast'alīq. Second, the Rajput kings figure prominently, closest to the emperor, in fact even higher than him (though the emperor has a halo and they do not). They each have two highranking Mughal officers by their side, but those officers are lower placed. Since those Mughal officers were among the highest office holders in the empire, to put them in an inferior position than Rajj Singh is obviously a biased portrayal. The portrait also illustrates the close relationship of the Kishangarh court with nearby Amber (soon to be transferred to Jaipur in 1727). We know that when Jai Singh besieged the Jat fortress of Thun in 1716 (his first, unsuccessful attempt, see Chandra 2002: 215; Dwivedi 1989: 61-6), Rāj Singh's son, Sāvant Singh was in his army and is said to have distinguished himself in courage during an attack to the extent that he was congratulated by the emperor (Śaran 1966: 12).

7 This miniature, in comparison with the slightly later Citarman miniature, illustrates well how the painting that Rāj Singh sponsored was on a par with, if not ahead of cosmopolitan developments in fine arts at the imperial court. Art historians have studied the close symbiosis of miniature art painting during Muhammad Shāh and Kishangarh, both stylistically and in terms of themes, on the basis of other paintings, particularly those portraying fireworks (Haidar 1995 and 2011; Singh 2013). In this example we see a bold move of Rāj Singh to have himself painted literally into prominence in the Mughal world and with some success. Given that Citarman slightly later painted his similar scene 
(without the Rajputs though), there is at least some ground to see this Kishangarhi painting as a model for the imperial one, though of course the latter is unique in its own way.

For our purpose it is also meaningful is that Rāj Singh's miniature suggests an acquaintance with Zafar Ḳhān Raushan ud-Daulah. The third Bakhshī was famed for his fabulous wealth and grand weekly soirées (majlis-e sam $\bar{a}$ ) to which he invited mystics, saints, as well as 'ulama and during which singers and musicians performed (see Malik 2006: 330-1, on the basis of the unpublished Tarikh-e Shahdat-e Farrukh Siyar-va julüs-e Muhammad Shāh by Muhammad Bakhsh Ashūb). This suggests a venue where Rāj Singh and his sons may have been present. If so, that may well have been the forum where they were exposed to the latest literary trends and the poetry and music in vogue at the time, including the then perceived to be new medium of Urdu (called Rekhtā at the time).

Rāj Singh's son Sāvant Singh was himself a poet under the pen name of Nāgrīdās and keenly followed the latest in literary trends. He compiled anthologies of 'greatest hits' of Braj Bhāșā Krishna devotional poetry, including one contextualizing the songs, his Padaprasanga-māāa, or 'Garland of stories about songs' (see Pauwels forthcoming). But he was also aware of the latest in the Mughal capital, and incorporated the new Rekhtā in the anthologies of his favorite poetry. The printed edition of his collection Pada-muktāvali, or 'String of Pearls,' includes two poems by the newly popular Valī and several 'response poems' by Nāgrīdās (Gupta 1965, vol. 1: 505-7; Pauwels 2012: 70-8). Recent manuscript study in Kishangarh has brought to light further evidence. In a manuscript of an anthology preserved in the Kishangarh royal library, I found not only two other Vali poems but also a Persian poem written in Devanāgarī. One might well speculate that he may have picked this up in Delhi, perhaps at one of the weekly soirées (majlis-e sam $\bar{a}^{c}$ ) organized by Zafar Ḳhān.

zindagānī dar jahān be yār kardan mushkil ast

ḥāl-e khud bah har kasī izhhār kardan mushkil ast

yakì migoì bah ḳhubam àshnā'ì mushkil ast

āshnā'ì mitavān kardan judā'ī mushkil ast

shishah-ye shikastah paivand kardan mushkil ast

yār-e dil ranjīdah rā khuśnūd kardan mushkil ast

(fol. 4v.)

Spending life in the world without a lover is difficult.

To reveal the state of one's mind before everyone is difficult.

The saying goes: 'to befriend the finest is difficult.'

To befriend is doable, but to split is difficult.

To glue a broken mirror is difficult.

To mend the broken heart of a lover is difficult.

Some folios further, we find a poem by Nāgrīdās (also attested in the printed edition of his works 757), that seems clearly inspired by this refrain:

\footnotetext{
an்khiyaũ se maĩ kahā thā, karau mata husana parastī

taba tau nahĩ rahī ye bica, syokha saramastī

aba biraha kī avāì, dila para parī hai tājīi

mujakaũ salāha kyā hai, musakala hai iskabājī

mana kistī hai sikastī, darīāva lagana maĩ gaharaĩ

tuja rūha rukha rakhũhi, uțhatī hai kahara laharai

aphasosa ke bhavara maĩ, rașaũ sadā diyā jī

mujakau salāha kyā hai, muskala hai iskabājī

merī dasā duhelī yaha, kisa kaũ kahi sunãu

parī prìta ke samada maĩ, kahũ pāra bhī na pãu
} 
nāgara navala piyāre tuma tau hau khusa-mijājī

muja kaũ salāha kyā hai, musakala hai iskabājī

(fol. 24v.-25r.; see also his Pada-muktāvalī 757; Gupta 1965, vol. 1: 502-503)

I beseeched my eyes: 'Don't worship beauty!'

They did not stay with me, [but] brazen with intoxication [went away]

Now loneliness has come, assaults my heart afresh.

What's your advice for me? The game of love is hard to play...

My heart's a broken ship, adrift on love's deep sea.

I steer a steady course to you, as fury's waves wash over me.

Through swirls of woe, I protect my little lamp of clay,

What's your advice for me? The game of love is hard to play...

This is my dire plight! In whom can I confide?

I drown in passion's ocean. I cannot reach the other side.

Nāgar says: 'My tender love, you are so carefree, say,

What's your advice for me? The game of love is hard to play...'

11 Obviously the refrain was inspiring but also the theme of unrequited love, so common in Persianate poetry. Nāgrīdās also naturally took to the Persianized vocabulary, which I have underlined in the text above, so it is apparent from a casual glance.

The same manuscript also contains some of Nāgrīdās' distychs (dohās) on the theme of love (fol. 54r.-55v.), some of which were later collected in his longer work Iśq-caman. In most versions the Iśq-caman starts off with four couplets, two of which are the following:

ujale maile khalaka mẽ, phaile majaba aneka

iskabāja siratāja kõ, iska piyārā eka

iskabāja vaisā na koü, vaisā sūrata khūba

nāgara mohana sãvalā, kadaradāna mahabūba

(Pada-muktāvalī Rekhtā 2-3; Gupta 1965, vol. 1: 508)

In the glittering fair of the world, many religions are on display,

But for the exquisite lover, his only faith is love.

There is no one like the lover, such a beautiful face!

Nāgar [says]: Mohana is the dark beloved, for those with sublime taste.

13 From these couplets, it is clear that the members of the Kishangarh court were not just exposed to the latest Urdu vogue in Delhi majlises, Sāvant Singh liked the new medium of 'Urdu' and made it a vehicle for his own poetry. However, it is also clear that he did not associate it with Islam, or see any contradiction with his own faith. For him, it was just another medium that could be pressed to use in celebrating his devotion to Krishna.

A Night in the Hot Season

INDIA, RAJASTHAN, KISHANgARH, CIRCA 1742 


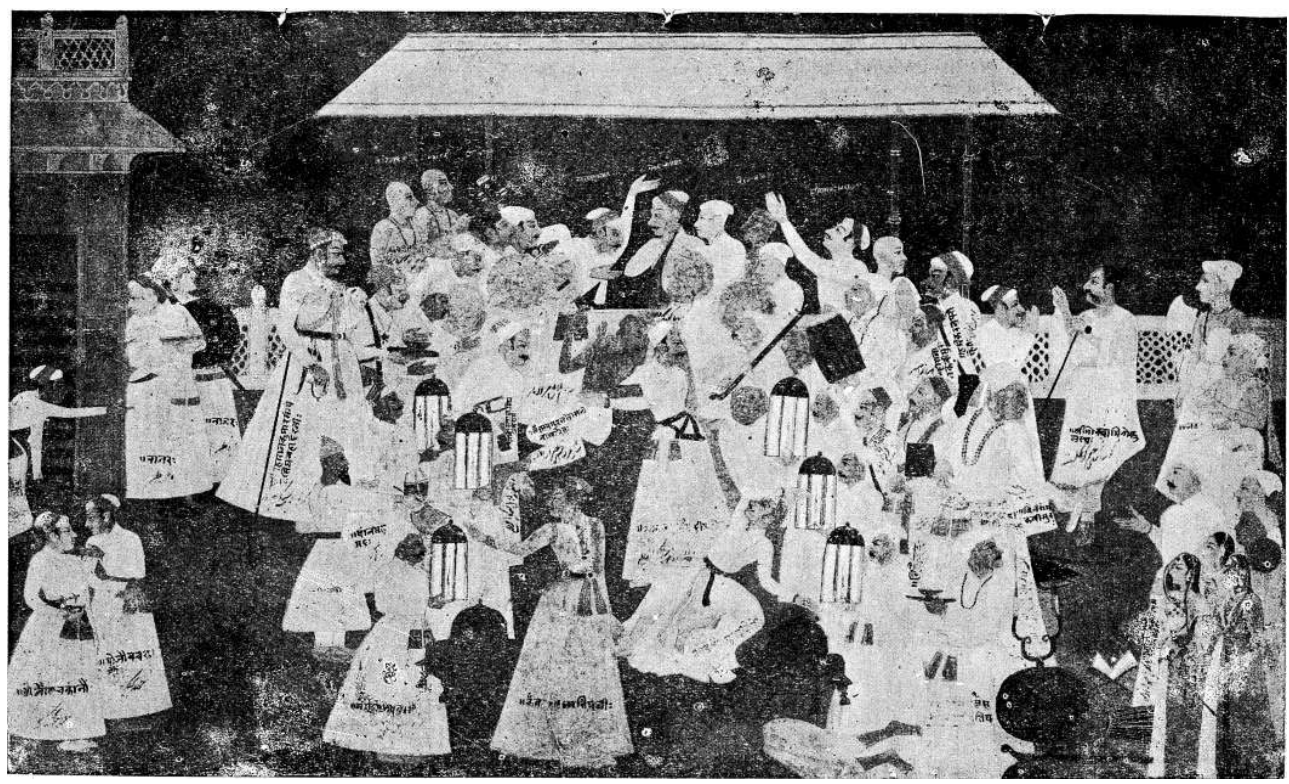

FORMERLY KISHANGARH ROYAL COLLECTION

\section{A Poetic Soirée in Kishangarh}

In the second miniature, Sāvant Singh is the one centrally portrayed (Plate 2; previously in the Kishangarh Royal Collection). ${ }^{8}$ The picture is of a much larger and less formal gathering, this time in the kingdom of Kishangarh. Its setting is a pavilion on a terrace overlooking the lake, so presumably it is set in the Kishangarh palace near Lake Gundalao (though Śaran says it is in Rupnagar). Alternatively it may depict a scene in Vrindaban, overlooking the river Yamun, just done in Kishangarhi style. In any case, it depicts an evening soirée, with several attendants holding lanterns. Here too the figures depicted are identified by inscriptions, but they are in two scripts: Devanāgarī and Nast'alīq. No date is given, but at the top of the miniature is an inscription that gives its title: Grīṣma Ritu Rātr: 'a night in the hot season," and indicates that it is a regular (nita) gathering during the time when Sāvant Singh was crown prince. ${ }^{10}$

While produced during his father's reign, the patron of the picture is likely to be 'Śrī Mahārājā Kumār Sāvant Singh Bahādur jì' himself, who is identified as such. He is shown in full regal attire, yet he is also holding a rosary in his right hand to indicate his devotion. The overall scene looks like an ecstatic kirtan party, with several devotees present, some with devotee cap, others shaven ascetics. Notwithstanding the apparent Vaiṣnava devotional character of the gathering, several Muslims are depicted attending, and there are also more 'secular' figures. Right beneath Nāgrīdās is a figure identified in the inscription as Khān Muhammad. This may be the Pīr Muhammad mentioned as receiving a very generous 100 Rs. a month allowance in a register of the employees of Rāj Singh (Śaran 1972: 255-6, fn. 2). ${ }^{11}$ There is another figure in the painting who looks Muslim due to the shape of his beard and headdress but the inscription is pretty much illegible. Behind the sponsor are two court officials, each identified as 'nāzir' (in Devanāgarī and Nast'alīq), one of them looking back at a young dark-skinned dancing boy (bacaknau) who is pulling his sash. ${ }^{12}$ In the left bottom corner are two other young 
dancing boys, Maujau and Ghojau. The latter is a handsome boy with prominent curled hairlock on his cheek, which seems coquettish and befitting a dancing boy.

The scene is reminiscent of descriptions we have of Delhi cosmopolitan gatherings, for instance from the contemporary work, the so-called Muraqqa'-e Dehli 'Marvels of Delhi' by the Deccani official Navāb Dargāh Qulī Ḳhān Bahādur Sālar Jang (1710-1766; see Khan 1989). That digest of the Delhi scene for Deccani aficionados was written on the basis of Dargāh Qulī Ḳhān's own experience during his sojourn in the capital from 1737 until 1741, providing a vivid picture of the city's multiple festivals, literary gatherings, and musical soirées (for a summary, see Hasan 1995: 15-33). The image reproduced here shows something similar taking place in Kishangarh. Besides the dancing boys, there are several musicians in the picture, some possibly also Muslim. Opposite the boys, in the right corner, three ladies are standing, looking on. Musical instruments are lying next to them on the floor and a manuscript lies open in a book holder, perhaps indicating that the ladies are singers that have been performing songs from the manuscript. The inscription reads Gunī Rālhal (or Shalhal) with her troupe (apne parikar sahit). The prominent presence of this troupe brings to mind a slightly later Kishangarhi painting by Amarcand of another moonlit night party, this one in Rupnagar and presided over by Sāvant Singh's son Sardār Singh (Dickinson and Khandalavala 1959: 39 plate x). Here the invited artists are foregrounded and identified as Panna Bāī and her troupe from Shāhjahānābād or Delhi. This singer is well-known as a famous Delhi performer, a student of Ni'mat Khān, she is even mentioned as țavāif Panā in the Muraqqa'-e Dehlī (Khan 1989: 121). While Sāvant Singh's earlier party likely featured a lesser-known artiste, it certainly foreshadows such later invitées from Delhi.

Apart from the Muslim officials and artists, several of the respected Kishangarh court poets from that time are identified by the inscriptions. A younger man is greeting an older one and receiving his blessings. He is identified as Vijairām Kavīsur, whose poetry is also quoted by Nāgrīdās in one of his works (Śrìmad Bhāgavata Pārāyaṇa Vidhi Prakāsa, Khān 1974: 213-4; see also Gupta 1965: 1.34-5). The elder is identified as Śrī Gosvāmī Goku [1]stha, ${ }^{13}$ possibly a Vallabhan Gosvāmī from Gokul. Behind him, there are two figures, one is fanning him, both are identified as Bhatț. Clearly the Gosvāmī was a respected guest. Behind Vijairām, are two figures with their backs turned to him, identified as Hemkaran Purohit and Hīrālāl Kavīsur. We know of the latter as a court poet (Gupta 1965: 1.34-5), who received a stipend of seven Rupees a month (according to the aforementioned register, Śaran 1972: 255-6, fn. 2). The man with the drum in front of them, another musician, is identified as Räghau. The man with the bag underneath is Vinaicand who is known to have been at the court (Gupta 1965, vol. 1: 34-5; he is also quoted in the Srimad Bhāgavata Pārāyaṇa Vidhi Prakāśa, see Khān 1974: 213-4). In front of him is a courtier, identified as Rāthhaur Bhitor Singh, behind whom again a Muslim appears, and the inscription reads Sūfī Asad (ullāh) Aphīm.

Several of the courtiers portrayed here are quoted in the same work, Nāgrīdās's Śrimad Bhāgavata Pārāyaṇa Vidhi Prakāśa, 'Spotlight on the manner of a full recitation of the Holy Bhāgavata-purāna' of 1742 (VS 1799). This connection allows us to tentatively date the painting to around the same period, since it depicts the same courtiers. More important, it gives us a sense of the type of gathering that is portrayed in the painting. The Srimad Bhāgavata Pārāyaṇa Vidhi Prakāśa is a remarkable text, ostensibly giving instructions for how to arrange for a religious festival where a full reading of Bhāgavata-purāna takes place. However, the text actually is a report of one such occasion organized by Sāvant 
Singh himself in the monsoon season of the year 1742. Contrary to what the title might lead us to believe, there is very little attention given to the particulars of the recitation and interpretation of the Sanskrit scripture $(k a t h \bar{a})$; rather we get a transcript of the poetry composed for the occasion and read at the outset and at the conclusion of the rite. The poems quoted are by Nāgrīdās himself, and by the main courtiers present, most prominently the aforementioned Vijairām, Sanāṛhya Hīrālāl, and Vinaicand depicted in our painting, but also others. ${ }^{14}$ This turns the work into something akin to the proceedings of a premodern poetry workshop. What is remarkable is that on this occasion, a typical Hindu festival seems to have been the background against which something akin to a contemporary Rekhtā mushā'irah was enacted. The conventions of those mushāirahs included an invitation that announced the basic conventions regards meter and rhyme scheme chosen for the occasion (tarah) via an exemplary verse (misra'-e tarah). The guests then would outdo each other in composing verse in that manner (see Naim 1989: 168). ${ }^{15}$ That is exactly what is going on in this work by Nāgrīdās. Fascinatingly, also quoted is Nāgrīdās's concubine ( $p \bar{a} s b a \bar{n})$, who wrote under the pen name Rasik Bihārī. While she is not depicted in the painting reproduced here, we do have a feminine presence in the form of the singer and her troupe in the right bottom corner of the painting.

Central in the painting though are the Vaisnava devotees. The central character is the man swooning and being caught by someone behind him. He is identified as Gangāduīyā Murlī Premī. It is likely that this is the Vaișnava Murlīdās from Braj, to whom Nāgrīdās refers repeatedly in his works. Collecting those literary references to read in conjunction with this picture is revealing for understanding the environment in which this soirée took place.

Nāgrīdās mentions a Murlīdās Gaudīya Syāmānandī in his Pada-prasañga-mālā:

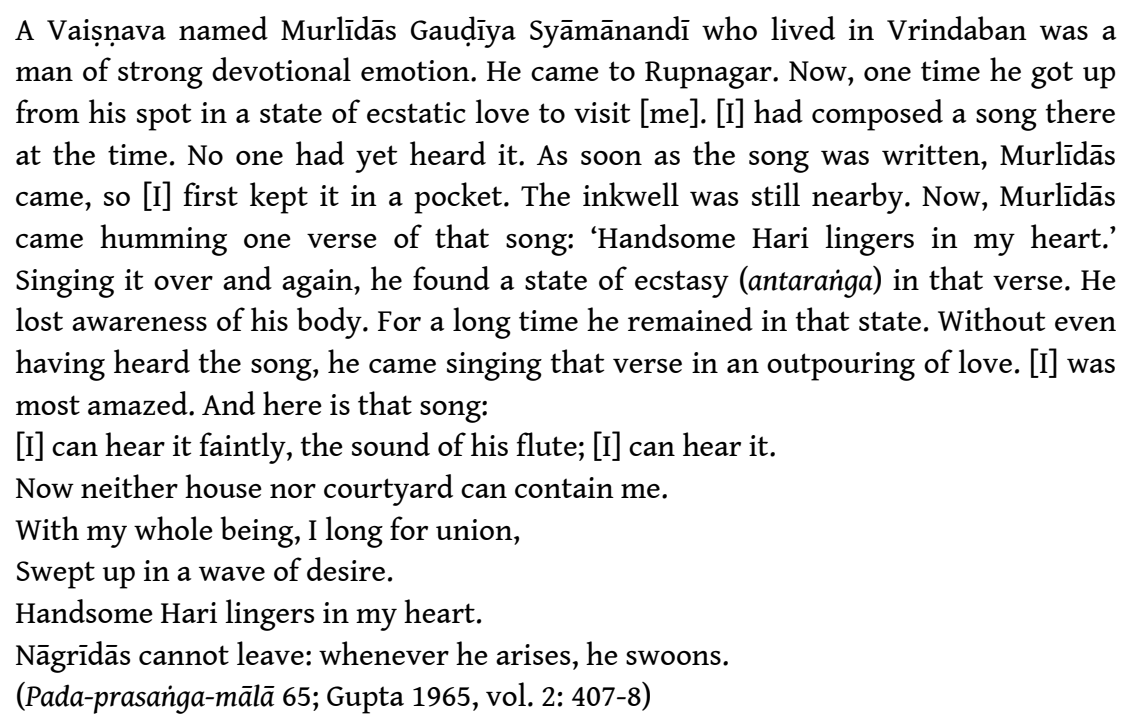

21 The point of this story is about Nāgrīdās' amazement over how the devotee Murlīdās would know a verse of Nāgrīdās's freshly composed song even before the song had been performed. In its lively detail about the pocket in which the paper was kept and the inkstand that was nearby, the story shows that Nāgrīdās had composed the poem in writing. The ink was not dry yet, so to speak, the song not yet published, when Murlīdās already knew it by heart. The incident shows an understanding of literature as floating around in a supernatural realm, where authorship means little, but bhaktas who 'tuned 
in' to this realm had instant access to each other's compositions. Murlīdās is literally on the same wavelength as his patron. He is shown as ecstatic and performing the crown prince's song. Such a portrayal fits the swooning man named Murlī Premī in the miniature. This vignette supports a surmise that something similar is going on in the picture.

In another prasanga of the same work, another Murlīdās is portrayed as a temple singer, a kirtaniya $\bar{a}$, in the Rupnagar temple, which is presumably Vallabhan:

During the days of the swing festival, Rupnagar's Lord, Śrī Govardhananātha, was swinging. In front of him, Murlīdās and other kìrtaniyās were singing songs. Now, the Lord became enchanted with one devotional song. Whenever the kirtaniyās sang that song, their singing brought abundant rainfall during the swinging. When they sang another song, the rain would cease. When they would sing this one [again], the downpour would return. The devotees and the temple servants all came to understand [this effect], so this song came to be requested at the time of the swing festival. Now, there were many festivals, such as the dinner of dedication ( nyauchvar bhog), but there was not a chance of a single raindrop from the sky. But then [when this song was sung] clouds gathered and there was a heavy downpour. The image became drenched. His little turban with the moon-jewel sagged, and his pearl necklace seemed to drip with rain. His holy body was beautiful. All became carried away in devotion (vimohita). So the song that had enchanted the Lord, Śri Govardhananātha, became famous for this effect. And here is that song:

As they sway breezily in the swing, the clouds drift in, [but] they do not [notice], caught up in conversation.

Swinging under the trees, they dodge fresh shoots, flowers opening, fruits of many kinds, and leaves.

[Holding on to] the pillars, they slow down gradually, and take shelter from the rain under a shawl.

Still Krishnadās' Giridhārī's clothes become soaked, his brows are heavy (with rain). Try as you will, you cannot stop [the downpour]. Why? The shiny cloud comes from the Lord's own body!

(Pada-prasanga-mālā 62; Gupta 1965, vol. 2: 405-6)

Given the strict rules of purity regarding Vallabhan images, this Murlīdās is probably not a Gaudiya. Our picture also does not show any image of a deity for whom the performance takes place. Still, we get an idea of the milieu in which songs were performed and the encouragement of ecstasy associated with songs perceived to have special powers.

Sāvant Singh also got together with a Murlīdās during his pilgrimage to the Radha and Krishna Kund in the Braj area, likely that was the same Murlīdās who visited Rupnagar as related above. We know of this meeting from Sāvant Singh's auto-biographical pilgrimage account Tìrthānanda (The Bliss of Pilgrimage). This work was written in 1753 (Māgh 1810 VS), and the pilgrimage may have taken place at some point around 1748 or 1749.

Description of Govardhan

12 We set out on foot, on the path around the mountain.

On the way many virtuous enthusiasts (rasikas) joined us:

Beautiful singing and kirtana, emotions streaming freely.

Many a cymbal (jhāñjh) clanging, and many a drum banging.

13 Cows and cowherds emerged from the forest, to listen along.

All ears, imbibing the nectar of Krș̣na's song.

A devoted (ananya) group was intoxicated with love:

Enthralled, concern for body and soul forgotten.

14 The group of enthusiasts arrived at the spot,

Where there is Radha Kund and Krishna Kund. 
Here too, fans gathered to listen with rapt attention.

They got up and lead us as bliss mounted.

15 We stopped as we approached Rupesura. ${ }^{16}$

Rivers of mutual love flowed on.

The mountain echoed back [our song], approving it without hesitation.

Some prostrated, embracing the earth.

16. There [we met] Bansīdās ${ }^{17}$ and Murlīdās.

Like great warriors of the Round Dance of Love:

They swooned on the battlefield of death.

Reclining on a bed of arrows, ${ }^{18}$ the [sharp] rise and fall of our melodies.

17. [In] joy of love broke the morning of devotion.

[The bliss we felt] I am unable to describe.

The divine couple's passion, its choice play,

We sang about it again. We had to force mind and body to leave.

18. We performed the circumambulation and returned to the camp.

On our way to Madhupurī (Mathurā), we left sad farewells in our wake.

(Tïrthānanda 12-18; Gupta 1965, vol. 2: 195-6)

Thus we hear of Murlīdās residing at Radha Kund, which enhances the likelihood of his being a Gaudiyya, as there was (and is) a strong Bengali presence in the place. He is described as ecstatically singing the praise of God, and swooning, all characteristic for Gaudīya devotion.

There is another interesting point about this passage, because in conjunction with Murlīdās, a Bansīiās is referred to. Bansīdās maybe the Vamíîdāsa, mentioned in one of the documents regarding the theological debates about whether Rādhā was Krishna's legally wedded wife (svakiy $\bar{a}$ ), or an adulteress (parakiy $\bar{a}$ ) (Horstmann 2009: 121). If so, it is possible that both he and Murlīās were followers of the unorthodox party of the Gaudiya Rūpa Kavirāj. This so-called Sauramya-mat was socially ostracized for its defiance of the Jaipur king Jai Singh II's measures to ensure religious orthodoxy for the Gaudiya Sampradāya since the 1720s. Thus, we see that notwithstanding the harmony between Kishangarh and Jaipur projected in our first painting, Rāj Singh's son associated with foes of Jai Singh's orthodox policies, the pariahs of the Gaudiya Sampradāya at the time (see Pauwels forthcoming). It is unclear though to what extent Nāgrīdās did so purposely, or whether it was an issue of a more accidental association. By the time Nāgrīdās undertook his pilgrimage (after 1748), Jai Singh had passed away and his successors were engaged in a dynastic struggle, so presumably the earlier religious orthodoxies did not matter so much anymore.

Pada-prasanga-mālā has also a vignette of a soirée that featured singing of kirtan on a smaller scale in a different setting, not in a temple, but in a private house, a haveli, in Rupnagar. The performers are kirtaniyās, presumably of the same Govarddhananātha temple mentioned before. The prasanga reads like a gossipy local newspaper report that could be titled: 'Fakir Falls from Roof':

In Rupnagar was a two-storied mansion. There, the kïrtaniyās were performing a kirtana session when a certain song stood out. Those who were particularly responsive to it became highly emotional upon hearing it. Then a stranger (vijātī) fakir became so enchanted by the song that in a fit of ecstasy he fell from the roof. That roof was so high that one could die even before reaching the ground. But the [fakir] survived the fall. [As he fell] he was singing that very song. And here is that song:

O friend, I do not know the way. Would someone tell me where he lives?

In these woods, all at once, he [came up and] embraced me delightfully. 
He stole my heart, and I do not [even] know his name-[just that] he had a handsome dark body.

Nāgrīdās: I have been robbed; I am without strength-a woman totally overpowered. My heart goes cold, my feet tremble, and heartless Kāmadeva strikes me on the head.

(Pada-prasañga-mālā 64; Gupta 1965, vol. 2: 407)

The incident shows the presence of a fakir, possibly a Sufi, at a kirtan session. This is very similar to what we see in the miniature. In the Pada-prasanga-māla more ecstatic than the others over the Krishna song. Such behavior for Sufis is reminiscent of such participation of Sufis in Hindu devotional sessions in Avadh, as documented by Muzaffar Alam. Alam has pointed out that such participation did not represent a straightforward case of intercommunal understanding, but was fraught with ambiguities (see Alam 1996: 183-5). ${ }^{19}$ One may realistically postulate that something similar was going on in Kishangarh, though we have no evidence at the moment of Kishangarhi Sufi or other discourses on the topic.

What is clear is that much is gained by reading the paintings in conjunction with the literary sources of the period. It is as if a new dimension is added: the static poses of the paintings come alive to the tune of music. We can almost hear the poetry, undoubtedly one of Nāgrīdās' songs, perhaps in the new Rekhtā, which led the devotee Murlīdās to swoon in the midst of a mixed-religious crowd at the hot season lamp-lit party.

\section{Conclusion}

The two paintings depicting mixed Hindu-Muslim meetings, when read together with the literature of the time, reveal instances of intellectual and artistic exchange between what are now regarded separate traditions: the Rādhā-Krishna Braj poetry on the one hand and the new vogue of 'Urdu' (then called Rekhtā) poetry on the other. We see that majlises in cosmopolitan Delhi, where Persian and the new Urdu poetry was recited, were positively received, even imitated in a milieu of Rādhā-Krishna devotees from seemingly provincial Kishangarh. And vice-versa, we see evidence that at bhajan sessions in Kishangarh Muslim dignitaries and Sufi fakirs were present, enjoying the Rādhā-Krishna poetry to the point of ecstatic abandon. In sum, we should then not think of the poetic traditions of Braj and Urdu as mutually exclusive. While a political agenda of Rajput assertion against Mughal overlordship was undoubtedly present, there was also evidence of joined celebrations of each other's poetical traditions.

\section{BIBLIOGRAPHY}

\section{Primary sources}

Editions of Nāgrīiās' Works (order of publication)

Gupta, Kiśorīlāl (1965) Nāgrīdās, Benares: Nāgarī Pracāriṇī Sabhā, 2 vol. 
Śaran, Vrajvallabh (1966) Śrī Nāgrīdāsjī kī Vāṇī: Nāgrīdāśjì ke Jīvanvrtta evaṃ Vāniyoṃ kā Sanśodhit Sanskaran, Vrindāban: Śrī Sarveśvar Press.

Khān, Faiyāz Alī (1974) Nāgrīdās Granthāvalī, New Delhi: Kendrīya Hindī Nideśālay.

\section{Other Editions/Translations}

Khan, Dargah Quli (trs. Chander Shekhar and Mitra Chenoy Sharma) (1989) Muraqq'a-e-Delhi: The Mughal Capital in Muhammad Shah's time, Delhi: Deputy Publ.

Lakhnawi, Shiv Das (tr. Askari, Syed Hasan) (1980) Shāhnāma Munawwar Kalām by Shiv Das Lakhnawi, Indian Council of Historical Research, Patna: Janaki Prakashan.

\section{Citations}

Alam, Muzaffar (1996) Assimilation from a Distance: Confrontation and Sufi Acoomodation in Awadh Society, in R. Champakalakshmi and S. Gopal (eds), Tradition, Dissent and Ideology: Essays in honour of Romila Thapar, Delhi: Oxford University Press, pp. 164-91.

Alam, Muzaffar. 1998. 'The Pursuit of Persian: Language in Mughal Politics' Modern Asian Studies, 32(2), pp. 317-49.

Bangha, Imre (2010) 'Rekhta: Poetry in Mixed Language: The Emergence of Khari Boli Literature in North India', in Francesca Orsini (ed.), Before the Divide: Hindi and Urdu Literary Culture. Hyderabad: Orient Longman, pp. 21-83.

Behl, Aditya; Weightman, Simon (trs) (2000) Madhumalati: An Indian Sufi Romance, Oxford World's Classics, Oxford: Oxford University Press.

Busch, Allison (2011) Poetry of Kings: The Classical Hindi Literature of Mughal India, New York: Oxford University Press.

Chandra, Satish (2002) Parties and Politics at the Mughal Court, 1707-1740, New Delhi: Oxford University Press.

Dalmia, Vasudha; Faruqui, Munis, (eds.) (forthcoming) Religious Interactions in Mughal India, Delhi: Oxford University Press.

Dickinson, Eric; Karl Khandalavala (1959) Kishangarh Paintings, New Delhi: Lalit Kalā Academy.

Digby, Simon (1975) ‘Abd al-Quddūs Gangohī (1456-1537 A.D.): The Personality and Attitudes of a Medieval Indian Sufi', in Khaliq Ahmad Nizami (ed.), Medieval India: A Miscellany, vol. 3, London: Asia Pub. House, pp. 1-66.

Dwivedi, Girish Chandra (1989) The Jats: Their Role in the Mughal Empire, Bangalore: Arnold Publishers.

Faruqi, Shamsur Rahman (2001) Early Urdu Literary Culture and History, New Delhi: Oxford University Press.

Faruqi, Shamsur Rahman (2003) 'A Long History of Urdu Literary Culture, Part 1: Naming and Placing a Literary Culture', in Sheldon Pollock (ed.), Literary Cultures in History: Reconstructions from South Asia, Berkeley: University of California Press, pp. 805-63.

Gilmartin, David; Lawrence, Bruce B. (eds.) (2000) Beyond Turk and Hindu: Rethinking Religious Identities in Islamicate South Asia, Gainesville: University Press of Florida.

Haidar, Navina Najat (1995) The Kishangarh School of Painting c. 1680-1850, Ph.D. dissertation, Oxford University. 
Haidar, Navina Najat (2011) 'Nihalcand'; in Milo C. Beach; Eberhart Fischer; B.N. Goswamy (eds.), Masters of Indian Painting, Artibus Asiae Publishers, Supplementum 48 I/II, vol. 2, pp. 595-606.

Hasan, Iqtida (1995) Later Moghuls and Urdu Literature, Lahore: Ferozsons.

Horstmann, Monika (2009) Der Zusammenhalt der Welt: Religiöse Herrschaftslegitimation und Religionspolitik Mahrājā Savāī Jaisinghs (1700-1743), Wiesbaden: Otto Harrassowitz.

Jackson, Anna; Jaffer, Amin (eds.) (2009) Maharaja: The Splendour of India's Courts, London: V\&A Publishing.

Malik, Zahir Uddin (2006 [1977]) The Reign of Muhammad Shah (1719-1748), New York: Asia Publishing House.

Marshall, D. N. (1967) Mughals in India: A Bibliographical Survey, New York: Asia Publishing House.

Matringe, Denis (1992) 'Krishnaite and Nath Elements in the Poetry of the Eighteenth Century Panjabi Sufi Bulhe Shah', in R.S. McGregor (ed.), Devotional Literature in South Asia: Current Research, 1985-1988, Cambridge: Cambridge University Press, pp. 190-206.

McInerney, Terence (2002) 'Mughal Painting during the reign of Muhammad Shah'; in Barbara Schmitz (ed.) After the Great Mughals: Paintings in Delhi and the Regional Courts in the $18^{\text {th }}$ and $19^{\text {th }}$ Centuries, Mumbai: Mārg Publications, vol. 53-54, pp. 12-33.

McInerney, Terence (2011) 'Dalchand', in Milo C. Beach; Eberhart Fischer; B.N. Goswamy (eds.), Masters of Indian Painting, Artibus Asiae Publishers, Supplementum 48 I/II, vol. 2, pp. 563-78.

Mittal, Sushil (ed.) (2003) Surprising Bedfellows: Hindus and Muslims in Medieval and Early Modern India, Lanham, MD: Lexington Books.

Naim, C. M. (1989) 'Poet-Audience Interaction at Urdu Musha'iras', in Christopher Shackle (ed.), Urdu and Muslim South Asia: Studies in Honour of Ralph Russell, London: School of Oriental and African Studies, pp. 167-73.

Orsini, Francesca (ed.) (2010) Before the Divide: Hindi and Urdu Literary Culture, Hyderabad: Orient Longman.

Pauwels, Heidi (1992) ‘A Sufi listening to Hindi Religious Poetry: Mīr ‘Abd al-Wāḥid Bilgrāmī’s Haqāyaq-i Hindī', Unpublished field paper, University of Washington website, URL: https:// digital.lib.washington.edu/researchworks/handle/1773/19592.

Pauwels, Heidi (2009) ‘Two Gardens of Love: Raskhān’s Prem-Vāṭikā and Nāgrīdās' Iśk-Caman', in Heidi Pauwels (ed.), Patronage and Popularisation, Pilgrimage and Procession: Channels of Transcultural Translation and Transmission in Modern and Pre-Modern South Asia, Wiesbaden: Harrassowitz, pp. 23-37.

Pauwels, Heidi (2012) 'Literary Moments of Exchange in the $18^{\text {th }}$ Century: The New Urdu Vogue Meets Krishna Bhakti', in Alka Patel; Karen Leonard (eds.), Indo-Muslim Cultures in Transition, Brill's Indological Library, vol. 38. Leiden: Brill, pp. 61-86.

Pauwels, Heidi (forthcoming) Pilgrims, Soldiers and Saints on the Move: Mobilizing Myth and Song in Eighteenth-Century North India.

Śarạ̣, Vrajvallabh (1972) Śrī Nimbārkācārya aur unkā sampradāya, Vrindāvan: Śrī Sarveśvar Press.

Singh, Kavita (2013) 'A Knowing Look: Appropriation and Subversion of the Mughal Idiom in Rajput Paintings of the Eighteenth Century', in Manuela de Giorgi; Annette Hoffmann; Nicola Suthor (eds.), Synergies in Visual Culture: Bildkulturen im Dialog, Paderborn, Germany: Wilhelm Fink, pp. 257-68. 
Sreenivasan, Ramya (2007) The Many Lives of a Rajput Queen: Heroic Pasts in India C. 1500-1900, Delhi: Permanent Black.

Sumahendra (1995) Splendid Style of Kishangarh Painting, Jaipur: Jaipur Printers.

Zebrowski, Mark (1997) Gold, Silver and Bronze from Mughal India, London: Alexandria Press.

\section{NOTES}

1. A first version of this paper was presented at the European Conference of South Asian Studies in Lisbon in July 2012. Research in India was made possible thanks to an AIIS senior short-term fellowship. The writing up of my findings was supported through a Guggenheim Fellowship and a Royalty Research Fellowship of the University of Washington. I am grateful to H.H. Maharaja Brajraj Singh of Kishangarh for kindly permitting and facilitating my studying the manuscripts in his family collection and to Madan Mohan Mukhiyājī of the Śrī Kalyāna Rāya temple for reading through the manuscripts with me. I am also grateful to the anonymous collector for his permission to publish the image here.

2. Rekhtā is a broader term with a long history, for which see Faruqi (2003) and Bangha (2010).

3. Previously published in Jackson and Jaffer (2009: 42, plate 28); Zebrowski (1997: 72, plate 54); McInerney (2011: 573-5, fig. 10). McInerney attributes it to Bhavānīdās's son Dalcand. His dating of the miniature is based on the fact that the emperor appears with a beard, which he shaved later in the 1720s (McInerney 2011: 573). See also the extensive discussion in Haidar (1995: 64-6), who is more inclined to attribute it to Bhavānīdās himself.

4. The inscriptions are not easy to read, but the following can be made out: Central top: 'Mahãmad Sāh Patisāh Gājij;' facing: 'Mahārājā Rāj Singh Bahādur Rāțhaur Banse;' next to him: 'Vazir Kamar uddīn Khān Bahādur Itmāddu Daulā.' Next: (illegible top portion) 'Bahādur Samasām udaulā Mansūr Jañg' and on his robe 'āthajārī mansab' (he was 8,000 mansab acc to Malik 2006: 67). Right behind the emperor: the inscription identifies 'Jai Singh Kachvāha Banse;' next to him: 'Bakhsī Japhar Khān Rausan Daulā;' next: 'Saādat Khān Bahādur Barhāma Mulk.'

5. Interestingly, the Mīr Bakhshī, Ḳhān-e Daurān, was in close alliance with Jai Singh and other Rajput nobles (for instance, in 1732 he had Jai Singh reappointed governor of Malwa; Malik 2006: 92-3). So the depiction of him with Rāj Singh, rather than Jai Singh may be more of wishful thinking. The alliance with Jai Singh was part of Ḳhān-e Daurān's faction-building against Qamr ud-Dīn Khān, who here is portrayed on the same side.

6. The edition of the work includes only four years of Muhammad Shāh's rule (Lakhnawi 1980: xiv). However, there is another version through the $28^{\text {th }}$ year called Iqbal Nāmah (mentioned by Marshall 1967: 447 n.1707). This version was unfortunately not available to me.

7. For this translation, I gratefully acknowledge the help of Sunil Sharma of Boston University, and Shahzad Shams and Alyssa Gabbay at the University of Washington, Seattle.

8. Previously published in Sumahendra (1995: 43), and Śaran (1966: facing p. 90).

9. For detailed views of the inscriptions, I am grateful to Dr. Navina Haidar of the Metropolitan Museum, New York.

10. The full Devanāgarī inscription on top of the miniature specifies (with similar information in the Persian version): yah bicitra citra mahārāja kumāra śrī sãvata singha bahādura jī dutiya harisambandha nãma śrī nāgarīdāsa jī ke rāta ke naita samāj kau yā samai ke adhikārīni sahita. "This amazing picture is of the regular (nita) gathering of crownprince Shri Savant Singh Bahādur II, whose religious name was Śrī Nāgrīdās, together with those entitled (to attend) at that time.'

11. Another possibility is that he is the same Muhammad as the one in the image of another musical party gathering portrayed by Amarcand, referred to below, who is there identified in 
that inscription as the mutavali of Ajmer (image reproduced in Dickinson and Khandalavala 1959: 39 plate $\mathrm{x})$.

12. His name is hard to read, perhaps Kejau.

13. It could possibly also be read as Grhastha.

14. In the introductory session, there is in addition poetry by Purohit Brajlāl, Kalhā Pannā (pen name Prānnāth). In the concluding section, in addition to work by the same authors, there are also Kavittas by Brinnāth Bhaț̣ and a Munshi Kanhīrām.

15. I am grateful to my colleague Dr. Jameel Ahmad at University of Washington of pointing me to this reference.

16. This may be a proper name of a devotee residing at Radha Kund (cf. the reference to a Rūpe Rasik in v. 133 of Tïrthānanda). Alternatively, it may be a deity: according to Pulin Gosvāmī of VRI in Vrindaban, there is a Śivalingam named Rūpeśvara, near Radha Kund (personal communication, July 16, 2011).

17. Possibly this is Vanśīdāsa, a follower of the unorthodox party of Rūpa Kavirāj, as explained below (see Horstmann 2009: 121).

18. They are compared to the great hero Bhīsma of the Mahābhārata, who rested on a bed of arrows until the self-chosen moment of his death.

19. For other literature on the topic of Sufis/Muslims and Hindus mixing in devotional gatherings prior to our period, see, among others, Digby (1975), Matringe (1992), Pauwels (1992, 2009), Behl \& Weightman (2000), Sreenivasan (2007), Busch (2011). More generally, see also Gilmartin and Lawrence (2000), Mittal (2003), Orsini (2010), and Dalmia and Faruqui forthcoming. Few though have reflected on the use of the new Rekhtā/Urdu for Hindu devotional purposes and what the audience might have been, which is the point here.

\section{ABSTRACTS}

This paper looks at poetic dialogues and exchange of ideas in eighteenth-century North India. The focus is on the reception of the new Urdu poetry (then called Rekhtā) in the lesser-known Rajasthani principality, Kishangarh. This small kingdom near Jaipur is known in the art world for its gorgeous paintings, especially the delicate depictions of the love of Rādhā and Krishna that have made the Kishangarhi school famous and give it an air of timelessness. Sometimes the school is also considered 'provincial'. Yet, there is more to this small principality than is commonly known. This paper shows how it was in fact quite cosmopolitan, very much in the midst of new intellectual and artistic developments at the Mughal court in the first half of the eighteenth century under Mahārājā Rāj Singh (r. 1706-1748). The paper's point of departure consists of two Kishangarhi paintings that were produced during Rāj Singh's reign. Both pictures portray mixed Hindu-Muslim gatherings. They show how there was more to the culture of Kishangarh than the world of Braj Bhāṣā poetry about Rādhā and Krishna. I read these paintings in conjunction with literary material that illustrates that in Kishangarh there were also experiments with the then-new style of poetry, later called Urdu. I present evidence of poetic dialogues between what are now regarded as separate poetic traditions, Urdu and Braj. The paper is based on recent manuscript research in India of Kishangarhi poems and collections. Methodologically it seeks to establish what can be gained in understanding by reading paintings together with contemporary literary sources. 
INDEX

Keywords: Kishangarh, Delhi, Mughal, Rajasthan, Urdu, Hindi, Braj, Indo-Muslim, mushaira, Krishna, bhakti

\section{AUTHOR}

\section{HEIDI PAUWELS}

Professor, Department of Asian Languages and Literature, University of Washington, Seattle 